\title{
Sedimentological analyses of the Upper Cretaceous and Lower Eocene carbonate successions in the Mateur-Beja area (NW of Tunisia): effects of tectonic regime on sedimentation
}

\author{
Fehmy Belghouthi ${ }^{1} \cdot$ Achref Zouari $^{2} \cdot$ Hedi Zouari ${ }^{3}$ \\ Received: 15 July 2019 / Accepted: 5 September 2019 /Published online: 16 October 2019 \\ (C) The Author(s) 2019
}

\begin{abstract}
The northwestern Tunisian Mateur-Beja domain comprises a thick succession of carbonate units belonging to the Late Cretaceous (Abiod Formation) and the Early Eocene times (Bou Dabbous Formation and its lateral equivalent). Sedimentological analyses were carried out on these sedimentary units with regard to their paleogeographic reconstructions. Three sections from the Upper Cretaceous and ten sections from the Lower Eocene successions were selected and correlated through the study area. The Upper Cretaceous Abiod Formation is composed of foraminiferal biomicrite limestones and marls deposited in outer platform to basin environments located slightly below storm wave base. The Lower Eocene carbonate successions are characterized by various storm-induced coarse- and fine-grained facies deposited in inner platform to basinal environments. Both carbonate units are characterized by significant lateral variations in thickness and facies. Close inspections show that thickness and facies variations were especially caused by synsedimentary major fault activity and locally by halokinetic movements. Comparison between the two studied units suggests that the changes of tectonic regime would have had significant impacts on thickness and facies distribution. Thus, the Upper Cretaceous and Lower Eocene carbonate deposits are interpreted in tectonically controlled basins.
\end{abstract}

Keywords Upper Cretaceous $\cdot$ Eocene $\cdot$ Carbonates $\cdot$ Sedimentology $\cdot$ NW of Tunisia

\section{Introduction}

Many sedimentary criteria of sedimentary deposits have been used as evidences of synsedimentary tectonic movements. Lateral variations of thicknesses and facies of sedimentary series close to faults are usually interpreted as being produced

Responsible Editor: François Roure

This paper was selected from the 1 st Conference of the Arabian Journal of Geosciences (CAJG), Tunisia 2018

Fehmy Belghouthi

fehmy.belghouthi@yahoo.fr

1 Faculty of Sciences of Bizerte, Carthage University, 7021 Jarzouna, Tunisia

2 Faculty of Mathematical, Physical and Natural Sciences of Tunis, Campus Universitaire El-Manar, University of El Manar, El Manar, 2092 Tunis, Tunisia

3 Water Researches and Technologies Centre, Technopark of Borj Cedria. Natural Water Treatment Laboratory, P.O. Box 273, Touristic Zone of Borj Cedria, 8020 Soliman, Tunisia by the synsedimentary activity of the faults. Thus, thicknesses and facies data of sedimentary series deposited in tectonically controlled sedimentary basins could be considered as useful tools for reconstructing their tectonic evolutions.

The northern Tunisian domain belongs to the northern Tunisian Tell; it is made up of many carbonate lithologic units interpreted as deposited in tectonically controlled sedimentary basins developed during various tectonic epochs (e.g., Castany 1951; Burollet 1956; Kujawski 1969; Rouvier 1985; Zargouni 1985; Ben Ayed 1986; Martinez and Truillet 1987; Zouari 1995; Zouari et al. 1999; Ben Salem 2002; Dlala 2002; Belayouni et al. 2012). The Upper Cretaceous and Lower Eocene carbonate units are the best-known formations owing to their widespread appearances in outcrops. In the MateurBeja area, NW of Tunisia, these carbonate units are both composed of alternations of limestones and marls displaying significant variations in thicknesses and facies especially in the vicinity of major faults. Detailed interpretation of the depositional environments of the two mentioned carbonate units allows us to interpret them as being controlled by tectonic movements. The present paper aims to (i) describe the sedimentary facies and thicknesses of the Upper Cretaceous and Lower Eocene units 
and (ii) interpret the effects of tectonic regime on the sedimentary record inferred from facies and thicknesses data.

\section{Geologic background}

\section{Paleogeographic framework}

Paleogeographic reconstructions of the northwestern Tunisian domain during the Late Cretaceous and Early Eocene point to drastic changes in sedimentary depositional environments (e.g., Burollet 1956; Fournié 1978; Bishop 1988; Negra 1994; Zaïer et al. 1998; Troudi 1998). During the Late Cretaceous (Fig. 1a), sedimentation took place in open marine deepwater environments characterized by relatively calm conditions (Burollet 1956; Mejri et al. 2006). Sedimentary series formed in these environments are composed of hemipelagic and pelagic sediments-comprised fine-grained limestone and marl (e.g., Burollet 1956; Negra 1994). Moreover, the Upper Cretaceous sedimentary carbonate series display significant lateral variations in thicknesses and facies which are interpreted by authors as resulted from irregular structuration of the seafloor into tilted subsiding basins developed under an extensional Upper Cretaceous tectonic regime (Martinez and Truillet 1987; Negra 1994; Bouaziz et al. 2002; Dlala 2002; Belayouni et al. 2012). During the Early Eocene (Fig. 1b), paleogeography was characterized by numerous submarine highs and lands which delimited shallow-water marine basins (Bishop 1988; Zaïer et al. 1998). This basinal architecture changes was interpreted by some authors as resulted in a part from the change of tectonic regime (El Ghali et al. 2003; Tlig et al. 2010; Belayouni et al. 2012) and/or halokinetic movements (Kujawski 1969; Perthuisot 1981; Zaïer et al. 1998).

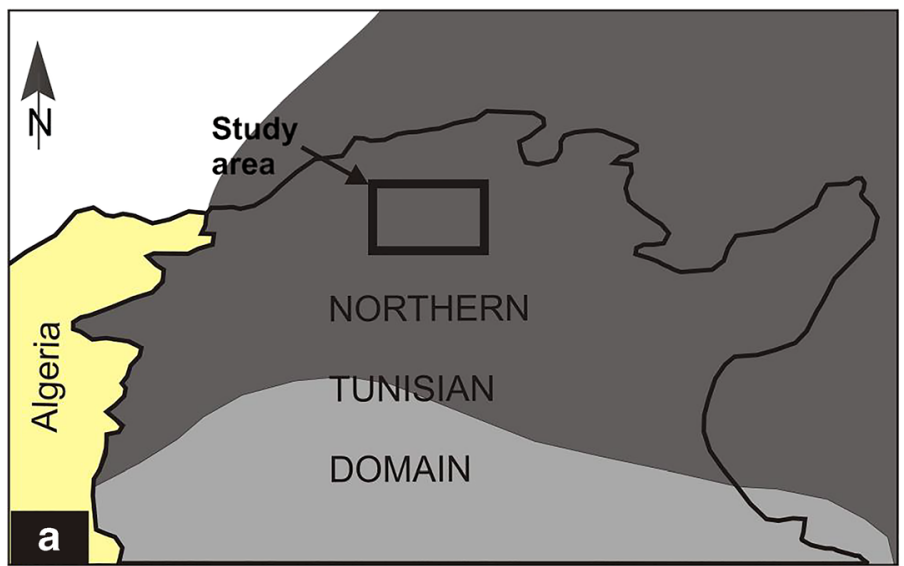

$100 \mathrm{~km}$

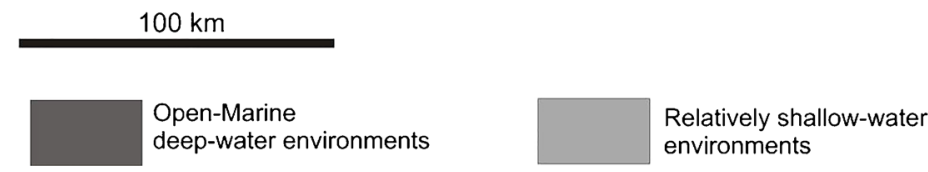

environments deep-water environments

Fig. 1 Paleogeographic maps of the northern Tunisian domain during a the Late Cretaceous (after, Troudi 1998) and b the Early Eocene (Bishop 1988; Zaïer et al. 1998) times

\section{Structural framework}

The northern Tunisian domain is located in the southeastern part of the North African chain belts, called the "Maghrébides." The formation of the "Maghrébides" chain is related to the collision between the European and African plates which reached its climax during the Miocene period (Durand Delga 1980). The "Maghrébides" chain is made up of roughly NE-SW-trending anticline and syncline structures composed of Mesozoic and Cenozoic lithologic units marked by saliferous Triassic diapirs (Zargouni 1985; Ben Ayed 1986).

The study area is located close to major fault alignments known as the "Hairech-Ichkeul faults (HI)" which extend over several kilometers along the northern Tunisian domain (Fig. 2a). In the Mateur-Beja area, the HI is composed of complex fault systems roughly oriented following NE-SW trends. The northern and southern domains of the HI faults are composed of narrow-shaped anticlines separated by relatively wide syncline structures (Fig. 2b). The anticlines are composed of Upper Cretaceous-Paleocene limestone and marl deposits, while the synclines comprise younger rocks including Eocene to Quaternary deposits. Several Triassic diapirs such as the Bazina-Bou Krime, Sakkek, and Muncher appeared in these synclines.

\section{Stratigraphic series}

In the study area, the Upper Cretaceous carbonate series includes two main formations: the Turonian-Lower Campanian Kef Formation (Fournié 1978) and the Upper CampanianLower Maastrichtian Abiod Formation (Burollet 1956). The Kef Formation is dominantly composed of dark-gray marl

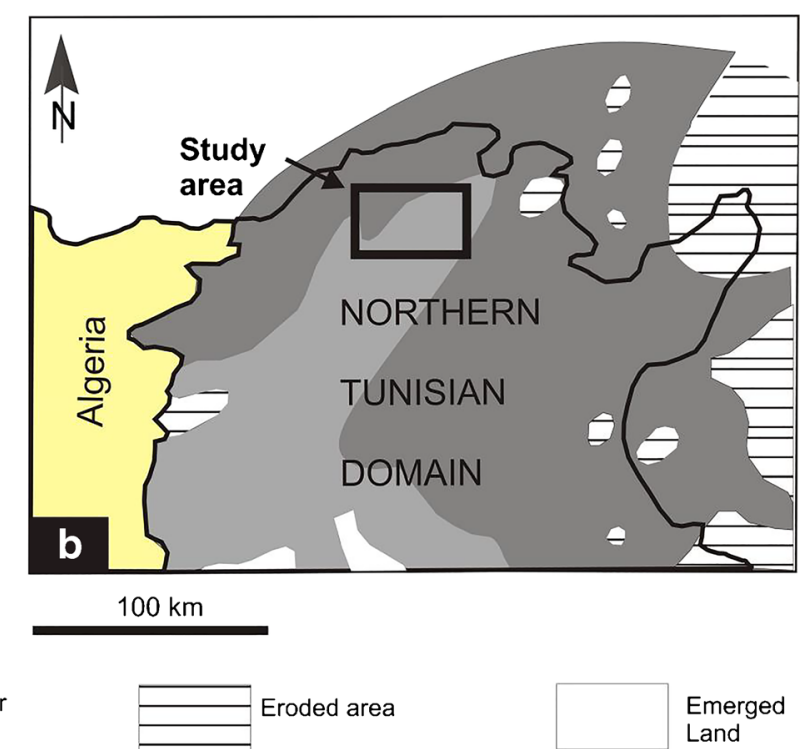
Springer 

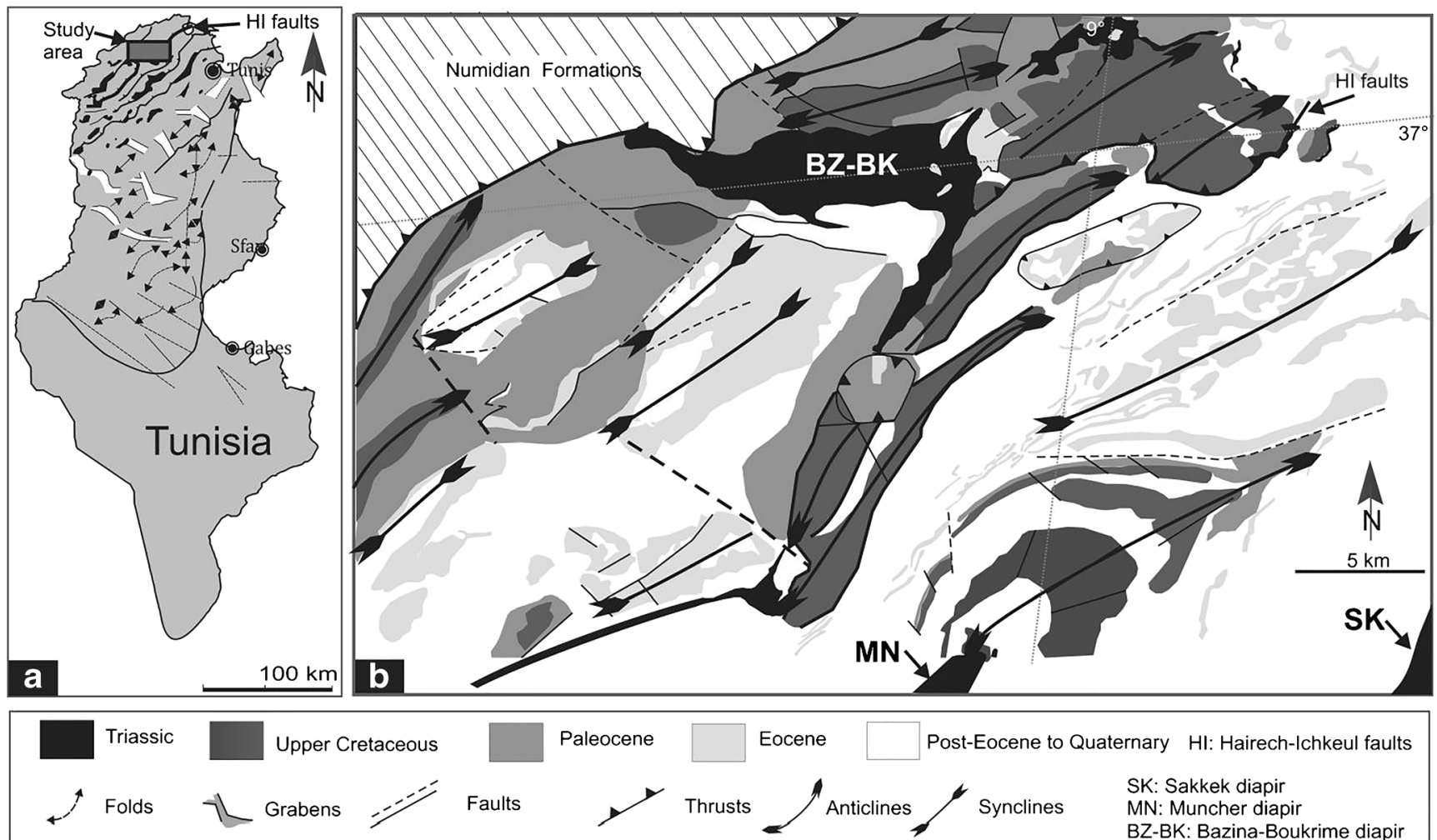

Paleocene
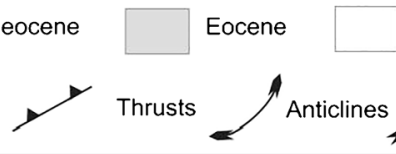

Post-Eocene to Quaternary $\mathrm{HI}$ : Hairech-Ichkeul faults

Fig. 2 Geologic maps and location of the study area. series and major structural elements of the study area

containing a few meter-thick argillaceous limestone bundles. The Abiod Formation is composed of two limestone members separated by a marl-dominated middle member. The thickness of the Abiod Formation varies from 200 to $500 \mathrm{~m}$. The Lower Eocene series, including the Bou Dabbous Formation (Fournié 1978) and its lateral equivalents, is composed of 10 to 140-m-thick limestone and marl alternations dated Late Paleocene-Early Lutetian in age (Kujawski 1969; Fournet 2001; Belayouni et al. 2012).

\section{Methods}

The Upper Cretaceous Abiod and the Lower Eocene Bou Dabbous Formations have been examined in numerous sites from the study area. Three field sections have been chosen from the Abiod Formation and ten field sections from the Bou Dabbous Formations. Sedimentary series were directly measured in field, described, sampled, and correlated. Trace fossils were described in field while their abundance was accurately measured in beds. Rock textures were determined following Folk (1962), Dunham (1962), and Flügel (2010) classifications. Microfacies characteristics including fossil content, grain size, and composition were described on thin section while relative proportions of grains were evaluated following point counting on $1 \mathrm{~cm}^{2}$ grid.

\section{Results}

\section{Thickness data and facies distribution and of the Upper Campanian-Lower Maastrichtian Abiod Formation}

Lateral correlation of the Upper Campanian-Lower Maastrichtian Abiod Formation displays a conspicuous thickening of the series north of the HI faults (Fig. 3). Thickness varies from $200 \mathrm{~m}$ south of the HI faults to 350 to $520 \mathrm{~m}$ to north. Thickness variations are associated with significant changes in facies. Facies analysis reveals the presence of two major lateral facies couplets: (i) distal storm-induced facies and (ii) muddy turbidites facies (Fig. 4).

Distal storm-induced facies are represented by foraminiferal-rich calcarenite limestone, silty marl, and white chalk. Calcarenite limestone occurs as 20- to 50-cm-thick beds commonly marked by erosional surfaces, gutter cast structures, wave- and current-induced asymmetric ripples, and abundant lithoclasts. These sedimentary features are interpreted as characteristics of high-energy storm-induced currents (e.g., Aigner 1982). Silty marl consists of metersized intervals, composed of lens-shaped calcarenite, and calcisiltite interbeds of 10 - to $25-\mathrm{cm}$ thick, finely crosslaminated, and commonly marked by undulating erosional 

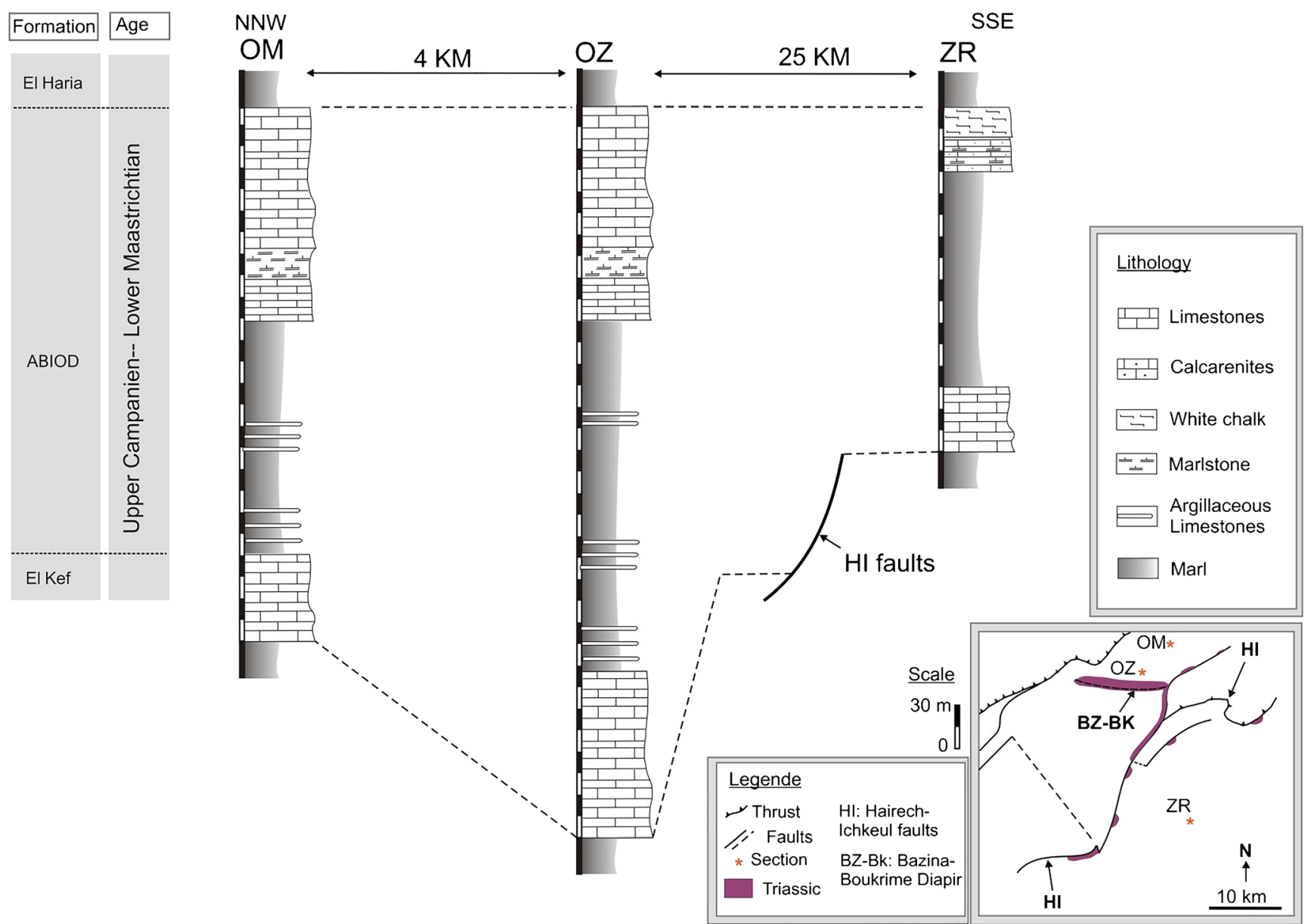

Fig. 3 Thickness correlation of the Upper Campanian-Lower Maastrichtian Abiod Formation in the study area

surfaces. These intervals were deposited by low-energy distal storm currents. The white chalk facies is composed of massive and occasionally laminated decimeter-thick beds, frequently marked by basal erosional surfaces, and showing planar to large-scale incurved laminations suggested to be formed by storm-combined flows. In terms of textures, distal storminduced deposits are commonly composed of moderately to well-sorted calcisphera/planktonic foraminifera-rich packstones and wackestones containing sparse benthic foraminifera, inoceramids, and sponge spicules.

Muddy turbidite facies is composed of laminated and bioturbated fine-grained limestone, marl, and chalky limestone deposits. Laminated limestone beds are $10-$ to $25-\mathrm{cm}$ thick, commonly marked by dark-colored millimeter-thick planar laminae occasionally composed of inoceramid prisms and lithoclasts. These laminae are similar to those described form muddy turbidites (e.g., Stow and Shanmugam 1980). Laminated limestone intervals are interbedded within 10 - to $60-\mathrm{cm}$ thick bioturbated intervals commonly composed of abundant trace fossils attributed to the Cruziana and Nereites ichnofacies. Both laminated and bioturbated beds are composed of foraminifera/ calcisphera-rich wackestone and packstone. Laminated beds are particularly composed of relatively sorted sediment enriched with inoceramid shell fragments, lithoclasts, and sparse benthic foraminifera (less than 10\%). These bioclast grains were transported by downslope lowdensity turbidity currents. Chalky limestone is composed of foraminifera-rich wackestone and mudstone usually bioturbated and frequently marked by hardground surfaces interpreted as deposited in starved outer platform environments (Belghouthi et al. 2019).

\section{Interpretations}

In northern Tunisia, the Upper Campanian-Lower Maastrichtian deposits have been interpreted as deepwater deposits (Burollet 1956; Negra 1994). From our observations, sedimentary structures reveal that these sediments were deposited in outer platform to basinal environments located around storm wave base (Fig. 5). The northern sector was located in deeper environments commonly acted as an area for the deposition of gravity-driven muddy turbidites. The absence of storm-induced structures in this sector suggests that it is located below storm wave base. The southern sector was relatively shallower, commonly dominated by the 


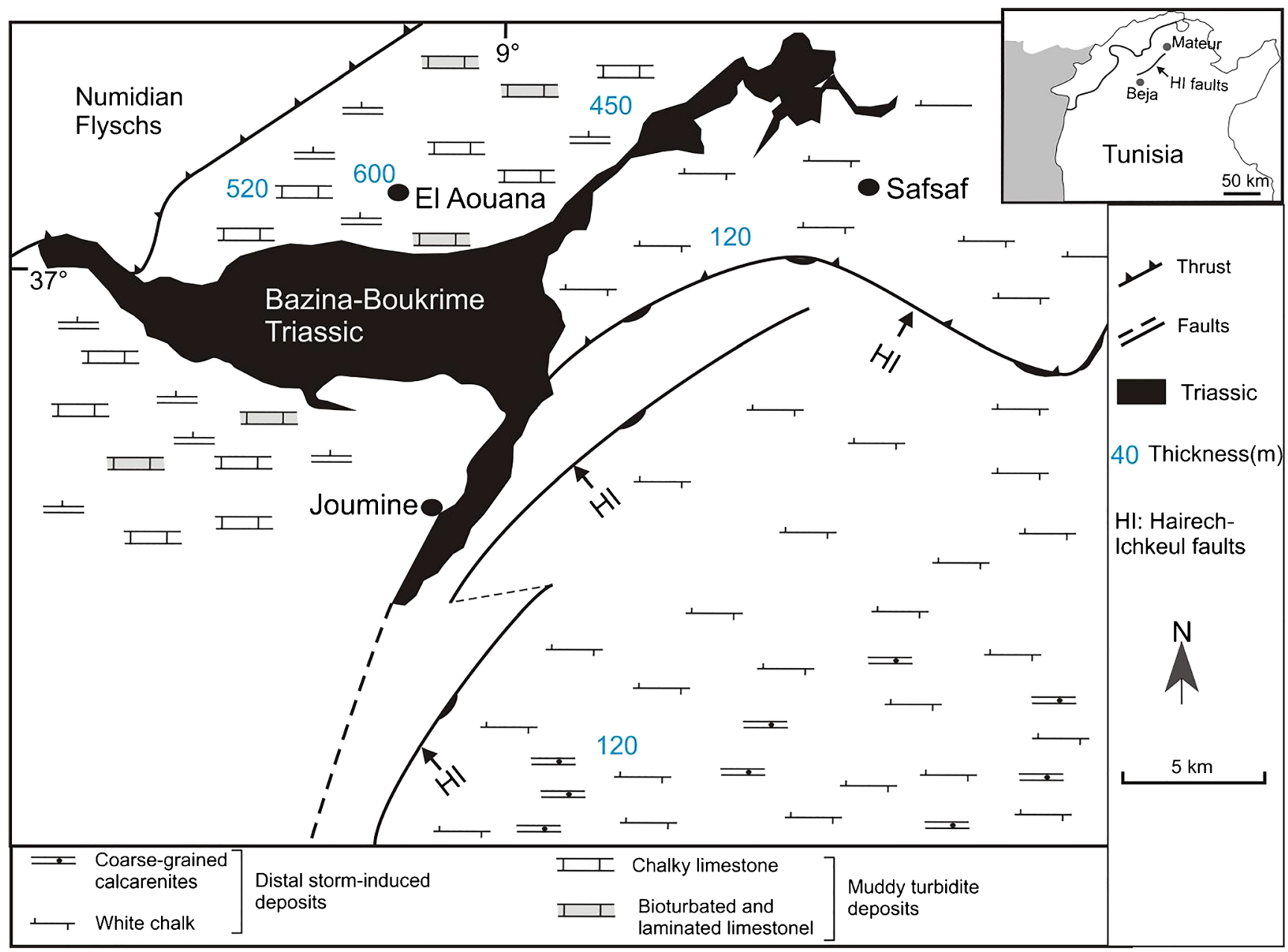

Fig. 4 Facies map showing facies distribution of the Upper Campanian-Lower Maastrichtian Abiod Formation

deposition of distal storm deposits. The southern and northern sectors were separated by slope represented by the HI faults which acted an area for the activity of downslope low-density turbidity currents. The predominance of low-density turbidity currents suggests a gentle sloping area separated the southern and northern blocks.

The significant increase of thickness in the NW sector of the HI faults suggests an increase of subsidence of this sector with respect to the southern one. This configuration implies graben-like geometry of seafloor probably generated by extensional tectonic movements of the Late Cretaceous (Martinez and Truillet 1987). Furthermore, the northern block was particularly marked by significant increases of thickness in the vicinity of Bazina-Bou Krime Triassic diapir. This increase of depth is interpreted as caused by synsedimentary subsidence of the El Aouana graben developed close to Bazina-Bou Krime Triassic diapir (Ben Mehrez et al. 2009; Belghouthi 2014). The synsedimentary active subsidence is supposed to be caused by synsedimentary movements of the Bazina-Bou Krime diapir (e.g., Ben Mehrez et al. 2009).

\section{Thickness data and facies distribution of the Lower Eocene Bou Dabbous Formation}

Correlation of the Lower Eocene Bou Dabbous Formation shows a significant thinning of the succession in the vicinity of $\mathrm{HI}$ faults (BJO, SN, BJ sections) and Bazina-Bou Krime Triassic diapir (Fig. 6). Thicknesses vary from 20 to $30 \mathrm{~m}$ in areas adjacent to the HI faults to 50 to $140 \mathrm{~m}$ in areas located beyond the HI faults.

In terms of facies, the Lower Eocene deposits are composed of coarse- and fine-grained deposits interpreted as induced by storm. Two major facies associations were recognized: (i) gravity-driven coarse-grained deposits and (ii) finegrained storm-dominated deposits (Fig. 7).

Gravity-driven coarse-grained deposits correspond to debris-flows-like and high-density turbidite-like deposits, presumably generated by storm in shallow marine areas and transported downward through a slopping zone (Belghouthi and Zouari 2019). They comprise conglomerates, breccia, shell-rich limestones, coarse calcarenites, and sandy (i.e., 


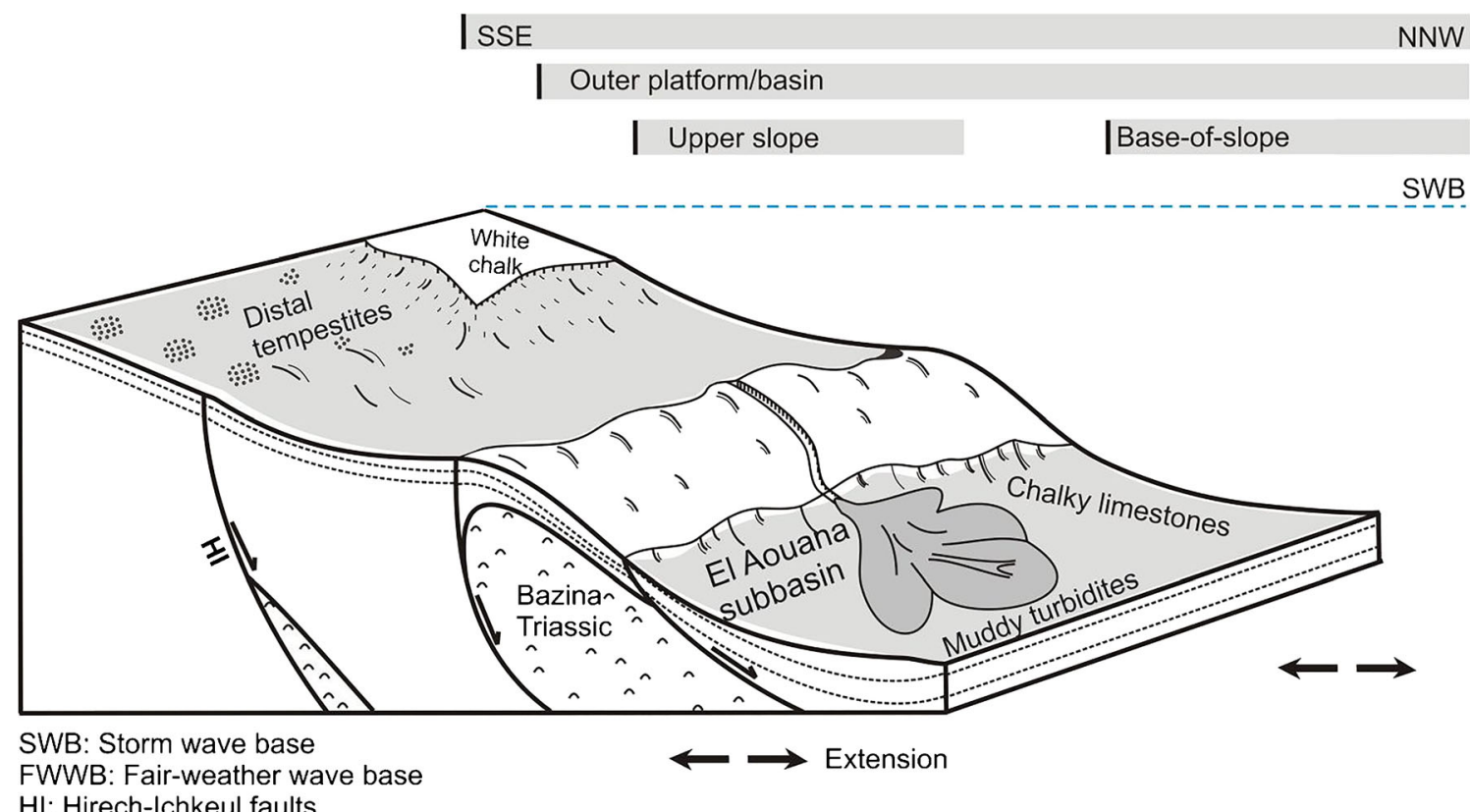

Fig. 5 Depositional environment interpretations of the Upper Campanian-Lower Maastrichtian Abiod Formation in the study area

sand-sized) glauconites. Conglomerates, breccia, and shellrich deposits occur as 10 - to 25 -cm-thick intervals dominantly composed of gravel-sized grains supported by a fine-grained matrix. Conglomerates and breccia are marked by globigerinid/calcisphera-rich calcisiltite matrix, while shellrich deposits are supported by fine-grained shell-derived

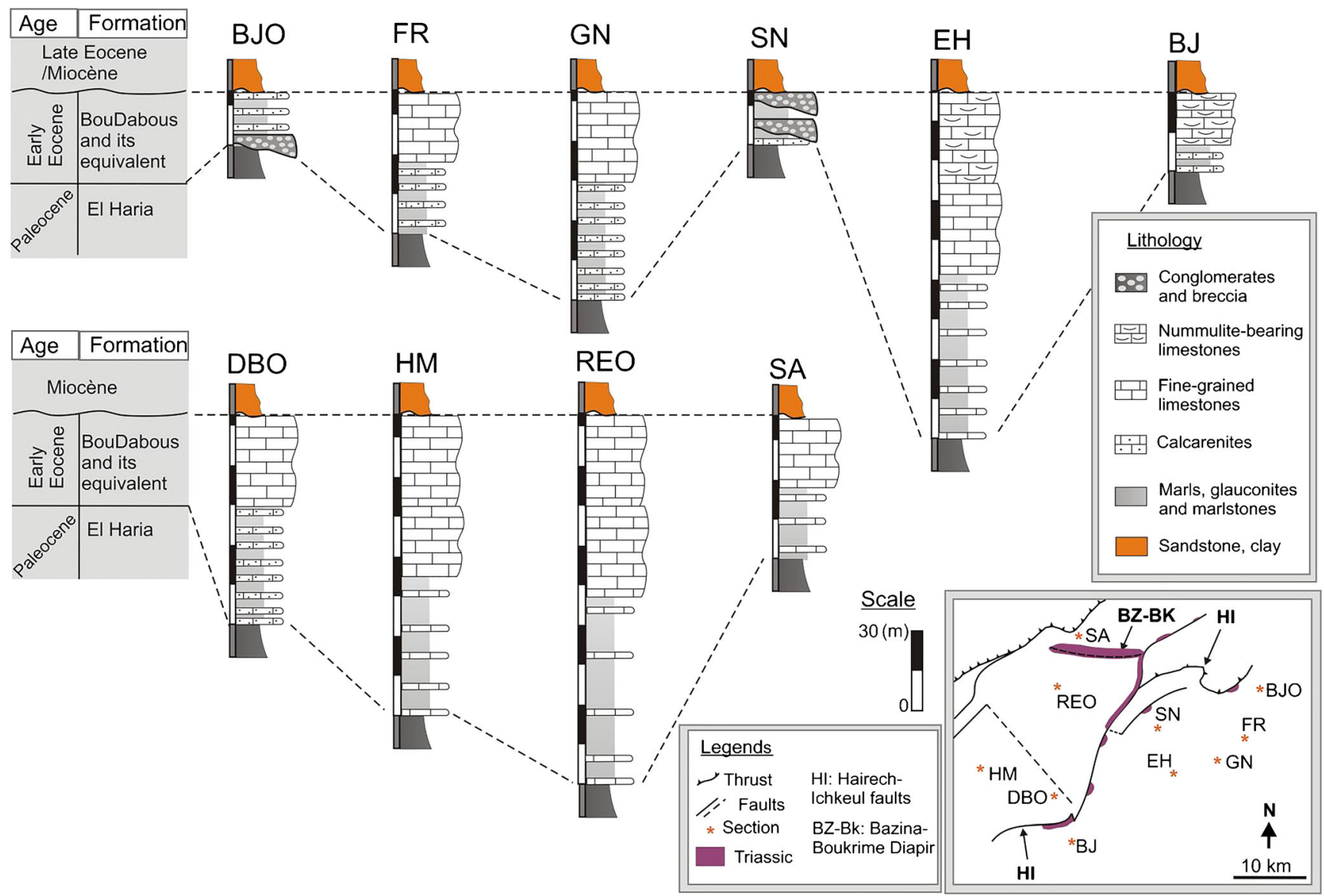

Fig. 6 Thickness correlation of the Lower Eocene Formation in the study area 


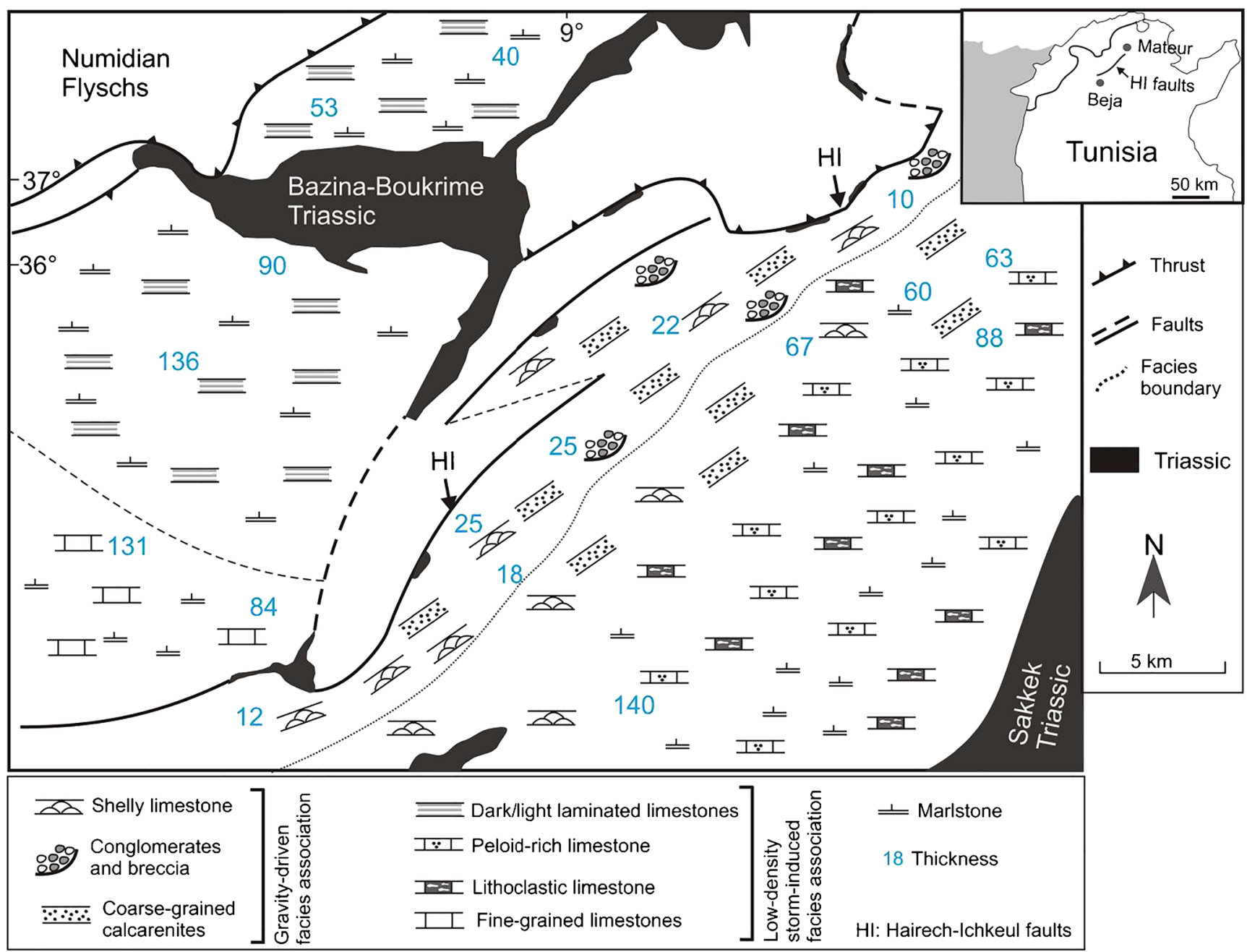

Fig. 7 Facies distribution of the Lower Eocene carbonate series

matrix. These deposits were generated by storm in highenergy shallow-water environments before they will be gravitationally transported into relatively deepwater environments. Coarse-grained calcarenites and sandy glauconites consist of decimeter-thick beds, usually structureless and occasionally marked by planar laminations testifying of deposition from high-density gravity-driven currents. The deposits are composed of glauconite/phosphate-rich matrix containing abundant benthic foraminifera, globigerinids, echinoderms, bivalves, peloids, and cortoids.

Fine-grained storm-dominated deposits comprise peloidrich limestones, lithoclastic limestones, calcisiltite limestones, and dark/gray laminated limestone interbedded within marl series. The first three facies occurs as centimeter- to decimeter-thick beds commonly marked by erosional surfaces, gutter casts structures, hummocky-cross stratification (HCS), wave-induced asymmetric ripples and current ripples. These structures bear evidences of deposition from stormcombined flows (e.g., Aigner 1982). The dark/gray laminated limestones are marked by planar to slightly undulated organic- rich laminae suggesting a deposition from low-density storminduced currents in areas located below the storm wave base. In terms of textures, storm-induced deposits correspond to relatively sorted packstones, wackestones, and occasionally, grainstones commonly composed of globigerinid/calcisphera, echinoderms, bivalves, nummulites, phosphates, and rarely quartz.

\section{Interpretations}

In the study area, the Lower Eocene deposits have been classically interpreted as deposited into two sedimentary environments: (i) nummulite-rich facies deposited in shallow marine platform, (ii) globigerinid-rich facies deposited in deepwater basins (Fournié 1978; Tlig et al. 2010). According to our observations, four major depositional sedimentary environments were inferred: (i) inner platform environments, (ii) shoal complex, (iii) middle-outer platform, and (iv) basin (Fig. 8). The inner platform is located between and storm wave base and fair-weather wave base. It occupies the 
southern block of the study area. The inner platform is dominated by the deposition of storm-dominated fine-grained deposits including peloid-rich, lithoclasts-rich, and calcisiltite limestones. Shoal complex corresponds to high-energy shallow marine highs located above the fair-weather wave base. This area extends parallel to the NE-SW-trending HI major faults, and it is represented by gravity-driven coarse-grained deposits. Facies data suggest that shoal complex and inner platform were separated by rugged slope acted as bypass zone for the transport of coarse-grained deposits.

The middle-outer platform and basin environments were located in the northern block of the study area. The middleouter platform environments are located at storm wave base as indicated by storm-induced structures. Sedimentation within such environments was dominated by fine-grained stormdominated deposits transported from shallow marine environments via storm-combined flows. Basinal area extends northward beyond the middle-outer platform. It is dominated by the deposition from low-density organic-rich deposits transported by storm currents and deposited in episodically confined environments located below the SWB.

The significant variations of facies and thicknesses in the vicinity of $\mathrm{HI}$ major faults suggest a synsedimentary activity of these faults. These faults were presumably acted as slopping bypass zones for the lateral transport of sediments. The southern side of these faults was marked by rugged slope dipping southward, while the northern side was rather marked by gentle slopping zone passing basinward. This configuration suggests tilted block geometry of the seafloor. In the northern block, there was a significant decrease of thickness close to the Bazina-Bou Krime diapir. Such features suggest that this diapir was active during sedimentation and that the obvious decrease of thickness was presumably caused by the dome-like geometry of seafloor caused by this diapir.

\section{Discussion}

\section{Changes of tectonic regimes}

In the literature, the Late Cretaceous and the Early Eocene times have been described as periods of distinct tectonic regimes. Late Cretaceous time is characterized by an extensional tectonic regime manifested by normal faults and graben and half-graben structures (Martinez and Truillet 1987; Negra 1994; Bouaziz et al. 2002; Dlala 2002; Belayouni et al. 2012). The Early Eocene time is described as period of "tectonic inversion" (El Ghali et al. 2003; Tlig et al. 2010; Belayouni et al. 2012) characterized by the onset of compressional tectonic phases.

Based on such interpretations, the study area would be structured during the Late Cretaceous into northward sloping graben-like or half-graben structures marked by the HI major faults. The latter probably acted as normal faults causing a deepening of the northern block with respect to the southern one. In contrast, during the Early Eocene tectonic inversion probably led to the reworking of the HI faults into reverse movement through which fault zone was reactivated into southward rugged slope and northward gentle slope. This would be caused during the deformation of seafloor probably during the onset of tectonic reverse movements. If it is so, the structural pattern of the study area during the Lower Eocene would be ascribed to growth syncline structures separated by the HI faults.

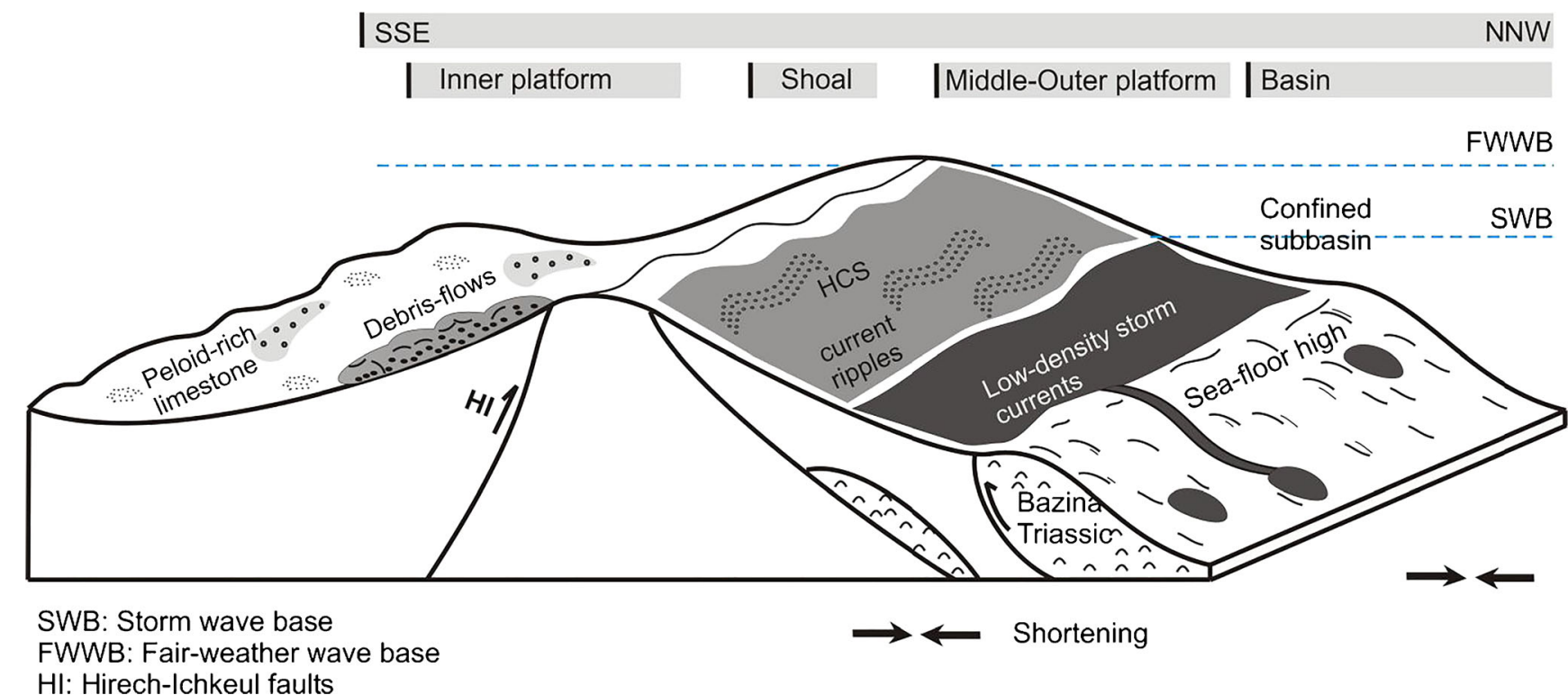

Fig. 8 3D interpretative block diagram showing the depositional environment interpretation of the Lower Eocene Formation in the study area 


\section{Effects of tectonic activity on sedimentation}

Comparing the Upper Cretaceous and the Lower Eocene deposits, tectonic activity appears to have significant influences on sedimentation. In both units, there was a synsedimentary control of facies and thickness distribution by major faults and locally, some Triassic diapir movements. The major impact of tectonic regime on sedimentation lies in the deformation of seafloor topography. Nonetheless, the slightly oblique to planar seafloor topography of the Upper Cretaceous was restructured into seafloor depressions separated by the major faults. This seafloor geometry was at the origin of formation of partially isolated subsiding sub-basins characterized by different environmental conditions; the northern basin was episodically confined and dominated by low-oxygen condition while the southern block oxygenated and calm conditions prevailed. Furthermore, the drastic change of seafloor topography led to significant variations in facies belts. The Upper Cretaceous facies show gradual lateral continuity of facies spectrum on either side of the major faults. For instance, the southern block was occupied by white chalk facies, which laterally passes into chalky limestones facies deposited in the northern block. The Lower Eocene facies was characterized by high-energy facies in inner platform and relatively low-energy facies in proximal inner and middle to outer platform. This facies belt was controlled by major fault activity.

The particular relationships between Triassic diapirs and subsiding areas suggest that such diapirs were controlled by subsidence, whether this was related to high sedimentation rates and/or tectonic movements of blocks. In both lithologic units, the impact of diapirs on sedimentation especially lies in the control of thickness. Thickness of sedimentary units displays a significant increase of thickness in submarine subbasins generated close to diapir or alternatively a prominent decrease in dome-like diapir morphology. This synsedimentary control of thickness could be related to the evolutionary steps of growth of diapir (e.g., Vendeville and Jackson 1992). In contrast, there are no drastic variations in facies were noticed close to diapir.

\section{Conclusions}

The Upper Cretaceous and the Lower Eocene carbonate units of northern Tunisia were deposited in tectonically controlled sedimentary basins developed during distinct tectonic regimes. Sedimentary data provided by these sedimentary successions show that tectonic activity controls facies and thickness distribution especially in areas located in the vicinity of major faults. During the Upper Cretaceous extensional regime, thicknesses and facies show gradual changes from shallow southern areas to deeper northern ones. This gradual change resulted on the formation of genetically related facies such as chalk and chalky limestone. In contrast during the Lower Eocene compressional regime, there was a subtle change in facies and thicknesses from the southern to the northern areas. Facies spectrum shows various and genetically unrelated facies generated by local separation of their depositional environments an irregular lateral continuity from shallower to deeper depositional environments due to fault inversion.

Acknowledgments Authors would like to thank CERTE, ETAP, and FSB for their supports of this study. We sincerely appreciate anonymous reviewers contributing to the enhancement of this paper.

Open Access This article is distributed under the terms of the Creative Commons Attribution 4.0 International License (http:// creativecommons.org/licenses/by/4.0/), which permits unrestricted use, distribution, and reproduction in any medium, provided you give appropriate credit to the original author(s) and the source, provide a link to the Creative Commons license, and indicate if changes were made.

\section{References}

Aigner T (1982) Calcareous tempestites: storm-dominated stratification in Upper Muschelkalk limestones (Middle Trias, SW-Germany). In Cyclic and event stratification, 180-198. Springer

Belayouni H, Guerrera F, Martín-Martín M, Serrano F (2012) Stratigraphic update of the Cenozoic sub-Numidian formations of the Tunisian Tell (North Africa): tectonic/sedimentary evolution and correlations along the Maghrebian Chain. J Afr Earth Sci 64:48-64

Belghouthi F (2014) Les Faciès des Formations Abiod et El Haria à Mateur: sédimentologie, environnements de dépôts et intérêt pétrolier. Faculté des Sciences de Bizerte. 150pp

Belghouthi F, Zouari H (2019) Storm-dominated shallow-marine carbonates of the lower Eocene succession of the northwestern Tunisian domain. J Afr Earth Sci 160:103608

Belghouthi F, Zouari H, Jeddi RS (2019) The lower Maastrichtian chalk in the Ghezala-Mateur area, northern Tunisian domain: sedimentary environments and early diagenetic features. J Afr Earth Sci 149: 291-306

Ben Ayed N (1986) Evolution tectonique de l'avant pays de la chaine alpine de Tunisie du début du Mésozoïque a ' l'Actuel. Thèse Doc Etat, Univ Paris Sud, France, 328 pp.

Ben Mehrez F, Kacem J, Dlala M (2009) Late Cretaceous synsedimentary diapirism of Bazina-Sidi Bou Krime Triassic evaporites (northern Tunisia): geodynamic implications. Compt Rendus Geosci 341(1): 78-84

Ben Salem H (2002) The cretaceous-Paleogene transition in Tunisia: general overview. Palaeogeogr Palaeoclimatol Palaeoecol 178: 139-143

Bishop WF (1988) Petroleum geology of east-central Tunisia. AAPG Bull 72(9):1033-1058

Bouaziz S, Barrier E, Soussi M, Turki MM, Zouari H (2002) Tectonic evolution of the northern African margin in Tunisia from paleostress data and sedimentary record. Tectonophysics 357(1-4):227-253

Burollet PF (1956) Contribution à l'étude stratigraphique de la Tunisie centrale. Ann Mines Géol 18:350

Castany G (1951) Etude géologique de l'Atlas Tunisien orientale. CR Somm Soc Géol Fr, p:359-360

Dlala M (2002) Les manifestations tectono-sédimentaires d'âge Campanien-Maastrichtien en Tunisie: implications sur l'évolution 
géodynamique de la marge Nord-Africaine. Compt Rendus Geosci 334(2):135-140

Dunham RJ (1962) Classification of carbonate rocks according to depositional texture. In: Hom, W.E. (Ed.), Classification of carbonate rocks, 1. American associations of petroleum geologists memorial, Tulsa, pp. 108-121

Durand Delga M (1980) La Méditerranée occidentale: étapes de sa genèse et problèmes structuraux liés à celle-ci. Mém h sér Soc géol Fr 10: 203-224

El Ghali A, Ben Ayed N, Bobier C, Zargouni F, Krima A (2003) Les manifestations tectoniques synsédimentaires associées à la compression éocène en Tunisie: implications paléogéographiques et structurales sur la marge Nord-Africaine. Compt Rendus Geosci 335(9):763-771

Folk RL (1962) Spectral subdivision of limestone types. In: Hom, W.E. (Ed.), Classification of carbonate rocks, 1. American associations of petroleum geologists memorial, Tulsa, pp. 62-84

Fournié D (1978) Nomenclature lithostratigraphique des séries du Crétacé supérieur au Tertiaire de Tunisie. Bull Cent Rech Expl Prod Elf Aquitaine 2(1):79-148

Fournet A (2001) Notice explicative de la carte géologique de la Tunisie à la $1 / 200000$, Mateur, Feuille ${ }^{\circ} 12$. Office National des mines, direction du service géologique, $36 \mathrm{p}$

Flügel E (2010) Microfaciès of carbonate rocks: analysis, interpretation and application. Springer Science \& Business Media

Kujawski H (1969) Contribution à l'étude géologique de la région des Hédil et du Bejaoua Oriental. Ann Mines Géol, 1969, 24 édition

Martinez C, Truillet R (1987) Évolution structurale et paléogéographie de la Tunisie. Memoria de la Societa Italiana de Geologia 38:35-45

Mejri F, Burollet PF, Ben Ferjeni A (2006) Petroleum geology of Tunisia: a renewed synthesis, vol. 22 ETAP, Memoir 230pp

Negra MH (1994) Les dépôts de plate-forme à bassin du Crétacé supérieur en Tunisie centro-septentrionale (Formation Abiod et faciès associés), stratigraphie, sédimentation, diagenèse et intérêt pétrolier. Thèses. Doct. d'Etat, Université de Tunis, p 649

Perthuisot V (1981) Diapirism in northern Tunisia. J Struct Geol 3:231235

Stow DAV, Shanmugam G (1980) Sequence of structures in fine-grained turbidites: comparison of recent deep-sea and ancient flysch sediments. Sediment Geol 25(1-2):23-42

Tlig S, Sahli S, Er-Raioui L, Alouani R, Mzoughi M (2010) Depositional environment controls on petroleum potential of the Eocene in the north of Tunisia. J Pet Sci Eng 71(3-4):91-105

Troudi H (1998) Les réservoirs et faciès associés du Crétacé supérieur en Tunisie Centrale : Sédimentologie, stratigraphie séquentielle et Diagenèse. Thèse d'Univ., Tunis, 287p

Rouvier H (1985) Géologie de l'extrême-Nord Tunisien : tectoniques et paléogéographies superposées à l'extrémité orientale de la chaine Nord-Maghrébine. Annales des mines et de la géologie, n²9:1985

Vendeville BC, Jackson MPA (1992) The rise of diapirs during thinskinned extension. Mar Pet Geol 9:331-353

Zaïer A, Beji-Sassi A, Sassi S, Moody RTJ (1998) Basin evolution and deposition during the Early Paleogene in Tunisia. Geol Soc Lond, Spec Publ 132(1):375-393

Zargouni F (1985) Tectonique de l'Atlas méridional de Tunisie. Evolution géodynamique et cinématique des structures en zone de cisaillement. Thèse ès Sciences, Université Louis Pasteur Strasbourg, 296p

Zouari H (1995) In: Univ. Tunis II (ed) Evolution géodynamique de l'Atlas centro-mèridional de la Tunisie: Stratigraphie, analyse géométrique, cinématique et tectono-sédimentaire. Thèse Doc. Etat, vol 278, Tunisie

Zouari H, Turki MM, Delteil J, Stephan JF (1999) Tectonique transtensive de la paléomarge tunisienne au cours de l'AptienCampanien. Bull Soc Geol Fr 170(3):295-301 